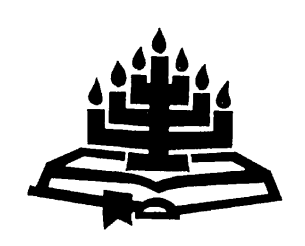

\title{
Piëtisme en die wyse waarop die leer van die sogenaamde second blessing beleef word: perspektiewe vanuit die Praktiese Teologie ${ }^{1}$
}

P.A. Rousseau, ${ }^{*}$ C.A. Venter \& C.J.H. Venter

Skool vir Kerkwetenskappe \&

*Skool vir Psigososiale Gedragswetenskappe

Potchefstroomkampus

Noordwes-Universiteit

POTCHEFSTROOM

E-pos: P214R@telkomsa.net

chris.venter@nwu.ac.za

casmar@lantic.net

\begin{abstract}
Pietism and the manner in which the doctrine of the so-called second blessing is experienced: perspectives from Practical Theology
\end{abstract}

The aim of the research underlying this article was to explore the experience of individuals supporting the form of pietism known as the so-called "second blessing" that implies successive works of grace. In this form of pietism sanctification is overemphasised at the expense of justification. In this article, a basis-theoretical assessment of core elements is followed by empirical-qualitative research data, more specifically the results of narrative analysis. A purposive sample of nine participants was used. The research data was obtained by means of a semi-structured questionnaire that the participants had to complete, as well as by a semi-structured interview that was conducted with each participant individually. The content analysis of the research data indicates possible reasons why some individuals favour this form of pietism, why some individuals do not favour this doctrine, why some individuals remain sup-

1 Hierdie artikel word opgedra aan 'n gewaardeerde vriend en kollega, prof. J.M. Vorster. 
porters of this form of pietism, and how some individuals are "freed" from it. Guidelines are given on a practice-theoretical level concerning the way in which the outcome of these results can be applied. An indication is given of the ways in which spiritual leaders, counsellors and other believers may find it useful to utilise the research data in their pastoral counselling of persons who practise this form of pietism.

\section{Opsomming}

\section{Piëtisme en die wyse waarop die leer van die sogenaamde second blessing beleef word: perspektiewe vanuit die Praktiese Teologie}

Die doel van die navorsing waarop hierdie artikel gebaseer is, was om die belewing van aanhangers van die vorm van piëtisme wat die sogenaamde "second blessing", of tweede genadewerk benadruk, te ondersoek. In hierdie vorm van piëtisme word heiligmaking oorbeklemtoon en die regverdigmaking afgeskaal. 'n Basisteoretiese beoordeling van kernelemente is onderneem, gevolg deur 'n empiries-kwalitatiewe en (meer spesifiek) narratiewe analise. 'n Doelgerigte steekproef van nege deelnemers is by die navorsing betrek. Die navorsingsdata is bekom deur 'n semi-gestruktureerde vraelys wat die deelnemers moes voltooi, asook 'n semi-gestruktureerde onderhoud wat individueel met die deelnemers gevoer is. Tydens die inhoudsanalise van die verkreë data kon redes aangedui word waarom sommige persone hierdie vorm van piëtistiese godsdiensbelewing aanhang, waarom sommige persone hierdie leer nie aanhang nie, waarom sommige persone hierdie vorm van piëtisme bly aanhang, en hoe persone daaruit "bevry" is of kan word. Daar is ook op praktyk-teoretiese vlak aangedui hoe geestelike leiers, beraders en ander gelowiges die verkreë resultate kan aanwend in hulle hantering en/of begeleiding van persone wat hierdie vorm van piëtisme aanhang.

\section{Basisteoretiese perspektiewe op enkele kernelemente}

\subsection{Die oorsprong van Piëtisme}

Die godsdiensverskynsel van die sewentiende en agtiende eeu wat later as Piëtisme bekend geword het, het nagenoeg in 1670 onder gelowiges van die Lutherse kerk in Duitsland ontstaan onder leiding van dr. Philipp J. Spener, die predikant van Frankfurt (Bloemhof, 1970:124; Trakakis, 2005). Die Lutherse Kerk was by tye en op sommige plekke oorheers deur 'n starre intellektualisme in die teologiese geledere. Dit het in die gemeentes die vorm aangeneem van ingewikkelde dogmatiese preke wat in hoogdrawende teologiese 
vakterme aangebied is. Die deursneelidmaat het bitter min verstaan van die leerstellige redenasies wat verkondig is (Bloemhof, 1970: 222), en 'n ontevrede reaksie van die lidmate het gevolg.

Spener het die kerkdienste aangevul met privaatbyeenkomste by sy huis. Tydens hierdie byeenkomste het hy sommige van sy preke herhaal en eksegese van geselekteerde Nuwe-Testamentiese gedeeltes aangebied. Die byeenkomste het later bekend gestaan as collegia pietatis (Anon., 2006) en die godsdienstige groepe wat op hierdie wyse gevorm is, is ecclesiolae in ecclesia ("a church within the church") genoem (Anon., 2006). Die publisering van Spener se werk Pia desideria (Engelse titel: Earnest desires for a reform of the True Evangelical Church) in 1675, het daartoe gelei dat hy en sy volgelinge Pietists genoem is (Anon., 2006).

Piëtiste se absolute afskeiding van wat beskou en beskryf is as die wêreld se sondes (die teater, dans, alle nie-godsdienstige leesstof Yannaras, 1984), was daarop gerig om 'n nuwe moraliteit tot stand te bring. Die Duitse Piëtisme was in hierdie opsig veral deur die Arminianisme beïnvloed en het net in ' $n$ ander vorm daarvan ontwikkel (Chung, 1995:5). Die individu se godsdiensbeoefening is so sterk beklemtoon dat dit beskou is as die bewys van iemand se persoonlike heiligheid. Die norm wat piëtistiese individue vir hierdie heiligheid gestel het, was daaglikse afsondering met lang tye van Bybellees en intense gebed. Hierdie afsondering het gepaard gegaan met 'n diepe selfondersoek, om sodoende verborge sondes te ontdek waarvolgens iemand - volgens bepaalde kriteria - sy eie vordering in persoonlike heiligmaking kon bepaal. Met hierdie "stiltetye" het/moes hulle aan mekaar bewyse gelewer het van hulle persoonlike toegewydheid. Hierdie praktyk het mettertyd meegebring dat die piëtiste op godsdienstige vlak met mekaar gekompeteer het (Rousseau, 2010:142).

\subsection{Piëteit en piëtisme}

Piëtisme as ' $n$ verskynsel in hedendaagse godsdiensbeoefening en -belewing, is nie algemeen bekend nie (Pearson, 2005). Die verskynsel kom egter wydverspreid in die Suid-Afrikaanse kerksfeer en ook wêreldwyd voor (Cilliers, 1997:3). Die relatiewe onbekendheid word aangehelp deurdat hierdie term baie keer as 'n sinoniem vir piëteit gebruik word. Die twee terme is egter nie sinonieme nie (Rousseau, 2010:139). Piëteit is die beskrywende term vir die normale toegewydheid van Christengelowiges, terwyl piëtisme dui op piëteit wat oordryf word. 
Piëtisme is die ekstreme vorm van piëteit en piëtistiese gelowiges word gekenmerk deur hulle wettisisme en rigiede vereistes vir godsdiensbeoefening en -uitlewing (Rousseau, 2010:10). Binne die raamwerk van so 'n godsdiensbelewenis en -beoefening kan die vorm van iemand se godsdiens (sý kerk, sý kerk se dogma, die liturgie, en selfs watter Bybel of -vertaling gelees word), so prominent wees dat mense "become converted to religion" en belas word met 'n vrag "religious performance" waarin en waardeur 'n sisteem of 'n dogma, in plaas van God, eintlik en uiteindelik gedien word (Johnson \& VanVonderen, 1991:165). In so 'n godsdiens word swaar klem gelê op die standaarde waarvolgens God gedien moet word, en waaraan gelowiges moet voldoen om God tevrede te stel (Saayman, 2006).

Piëtisme kan herken word aan twee hooffasette, naamlik die afskaal van regverdigmaking deur die feitlik eksklusiewe beklemtoning van heiligmaking, en die bevordering van subjektiwiteit in die beklemtoning van individualisme in heiligmaking (Brenner, 2007). In die geledere van evangeliese gelowiges geniet regverdigmaking en heiligmaking albei 'n sekere prominensie, maar by piëtisties-gedrewe vorms van die evangeliese stroming word heiligmaking beklemtoon ten koste van regverdigmaking.

Die beklemtoning van heiligmaking waarin regverdigmaking afgeskaal word, kom veral na vore in die vorm van piëtisme waarin ('n) opvolgende genadewerk(e) vir die gelowige as individu verkondig word (vgl. MacArthur, 1992:209). Die term second blessing figureer prominent in hierdie prediking waarin daar by individue aangedring word om na die vervulling met die Heilige Gees te soek.

\subsubsection{Die verlossing van inwonende sonde}

Die kernelement van die second blessing (of die tweede genadewerk in die leer van heiligmaking), is 'n verlossing van inwonende sonde (Rousseau, 2010:151) by ' $n$ individu en gelyktydig daarmee "word 'n kind van God vir die eerste maal vervul" (Mienie, 2009:4). Hierdie proses geskied wanneer 'n "bewustelike tweede krisis in die lewe van 'n kind van God" plaasvind (Coetzee, 2007:6). Tydens hierdie krisis sou 'n gelowige individu dan van inwonende sonde verlos word en dit is " $n$ algehele verwydering, die permanente uithaal van die inwonende sonde" (Beukes, s.a.). Coetzee (s.a.:11.74) beweer dat "[s]onder hierdie tweede ondervinding kan heiligmaking na die innerlike nie in die geestelike lewe voortgaan nie". Indien die tweede genadewerk dus nie realiseer nie, kan die proses van lewensheiliging na bekering nie voortgaan nie. 
So ' $n$ verlossing of verwydering is noodsaaklik by iemand wat tot geloof in Christus gekom het in ooreenstemming met die leer van die sogenaamde second blessing, aangesien hy/sy as vleeslik beskou word omdat sy inwonende sonde nog nie weggeneem is nie. Hierdie beskouing oor vleeslike gelowiges is afkomstig van ' $n$ Amerikaanse teoloog, dr. Lewis Sperry Chafer, na aanleiding van sy eksegese van 1 Korintiërs 2:15-3:3 (MacArthur, 1994:3). Daar word gestel dat 'n pas bekeerde mens nog "nooit die Heilige Gees as 'n inwonende fontein van lewe en blydskap en versadiging ontvang [het] nie" (Torrey, 1967:77) want, alhoewel "elke gelowige die Heilige Gees in 'n sekere sin het" (Torrey, 1967:87), is so 'n persoon nie vervul met die Heilige Gees nie. Hy het net die doop deur die Gees (by bekering) ontvang, maar is nie met die Gees gedoop nie. Hierdie doop met die Gees vind eers by die krisis van hartsreiniging plaas, wanneer 'n gelowige vir die eerste keer vervul word, dit wil sê mét die Gees gedoop word (Mienie, 2009:4). By die tweede krisis ontvang gelowiges dan ware heiligmaking en is dus geheilig. Iemand wat heiligmaking ontvang het, moet feitlik sondeloos kan lewe.

Hierdie leer is egter onversoenbaar met die Skrif. Eerstens, word beredeneer, is daar nie iets soos inwonende sonde nie en dus ook nie die moontlikheid dat so 'n inwoning deur 'n verlossing of algehele verwydering beëindig kan word nie. Die term inwonende sonde is geskep uit die hermeneuties bevraagtekenbare herfrasering van Paulus se stelwyse in Romeine 7:17 en 20. Romeine 7 is die parentese tussen hoofstuk 6 en 8 , waarin die apostel die realiteit van "alreeds, maar nog nie" van gelowiges se aardse lewe hanteer. In hierdie Skrifgedeelte bring Paulus die nederlae na vore wat gelowiges kan ly in hulle stryd om opreg te lewe. Die nederlae is te wyte aan "die sonde wat in my woon" (Bybel, 1999; 1983). Hierdie stelwyse, sowel in die oorspronklike as in Afrikaans, is duidelik: sonde is ' $n$ blywende realiteit in gelowiges se lewe; niemand is ooit finaal van sonde in hierdie lewe ontslae nie (Cloud, 2007). Hierdie realiteit spreek onbetwisbaar uit die oorspronklike

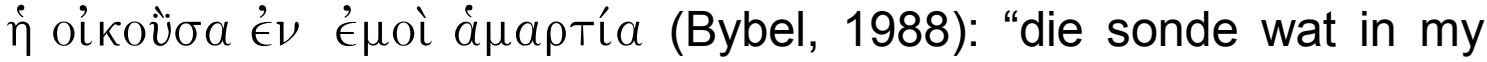
woon" (Rom. 7:17, 20). 'n Parafrase wat die onbeëindigbaarheid van sonde beklemtoon deur die praesens van die werkwoord te benadruk, sou kon lui "die voortdurend wonende in my sonde" (Rousseau, 2010:41). Die moontlikheid om te sondig vanweë die "altyd wonende sonde" in 'n gelowige is 'n stryd wat deur geen verlossing of verwydering beëindig kan word nie. 


\subsection{2 'n Tweede vervul-word met die Heilige Gees (die second blessing)}

Die begrip wat vir "vervulling" voorgehou word, is tweedens nie Skrifgetrou nie. Die imperatief in Efesiërs 5:18 word algemeen as 'n bewysteks ingespan om 'n bykomstige gebeurtenis vir individue te legitimeer. Die aandrang dat dit 'n opvolgende ("tweede") krisisgebeurtenis deur die Heilige Gees by individue moet wees, ten einde nie "vleeslike" Christene te bly nie, maar "geesvervulde" gelowiges te word (vgl. MacArthur, 1992:209), word baie sterk oorgedra. Beukes (s.a.) beklemtoon in 'n preek uit 1 Korintiërs 3:1-8 - waarin die vleeslike Christenskap waarna hierbo verwys is, hanteer word - dat die Skrif die vervulling met die Gees in Efesiërs 5:18 as 'n bykomende vereiste stel. Hierdie beklemtoning kom veral prominent in Coetzee (s.a.:6.24) se stelling na vore dat baie mans en vroue wat gered is, die geboortereg van die doop en die vervul wees met die Heilige Gees wat aan hulle behoort, nog nie vir hulleself toegeëien het nie. Die kinders van God (d.w.s. mense wat "alreeds die ondervinding van wedergeboorte deelagtig geword het"; Coetzee, s.a.: 6.23) word in Efesiërs 5:18 opgeroep om "ook met die Heilige Gees vervul te word".

Die verkeerde verstaan van die teks lei tot 'n foutiewe beklemtoning van 'n bykomstige ("tweede") en beslissende gebeurtenis in die lewe van elke individu (die sogenaamde second blessing). Die teks verwys egter nóg na 'n bykomstige geloofskrisis, nóg na 'n spreke tot individue, want die imperatief (deur die werkwoord in die meervoud), maan die gemeente/geloofsgemeenskap om altyd (deur die werkwoord in die praesens) met die Gees vervul te bly. Louw en Nida (1988, 2:691) stel ten opsigte van die werkwoord plēroûsthe (die praesens imperatief passief meervoud van plēróomai), dat dit in die subdomein "heeltemal" of "voldoende" dui op 'n volle deelname aan, of om ten volle by iets betrokke te wees ("to experience a complete degree of involvement in some event or state - 'to be completely, to be entirely, to be full of'"). In die konteks van Efesiërs 5 dui vervulling derhalwe nie op 'n "tweede", bykomende, individualistiese, geestelike ondervinding of herhaaldelike ondervindings nie, maar dit beskryf hoedat gelowiges binne 'n gemeenskap leef waarin die Gees van God werksaam is sonder dat die Gees bedroef word (vgl. Ef. 4:30). Die Gees van God oefen sy beheer ten volle uit: die gemeente is vervul en die Heilige Gees lei en bekragtig hulle om kinders van God te wees (Rom. 8:14, 16). 


\subsection{3 "Vleeslike" en "geestelike" gelowiges}

Derdens moet daarop gewys word dat die Skrif geen gegewens bied oor sogenaamde "vleeslike" gelowiges (diegene wat nog nie van die inwonende sonde gereinig is nie) of "geestelike" gelowiges (diegene van wie die inwonende sonde weggeneem is en wat die doop met die Gees ontvang het) nie. Gelowiges is mense wat in Christus, vanweë die Gees, aan Christus behoort (Rom. 8:9b). Vanweë die stelreël in hierdie leer dat alle weergebore mense wat nog nie die sogenaamde second blessing vir hulself toegeëien het nie, nog steeds vleeslik is, bring hierdie leer mee dat die nuwe skepping in Christus (2 Kor. 5:17) as gebrekkig beskou word. Die aanname van hierdie leer is ook dat alle gelowiges 'n opvolgende genadewerk moet ontvang (Rousseau, 2010:184) as die gebrekkige gelowige daarna soek en as God dit toelaat, en dat die volheid van die Heilige Gees dan eers die gelowige se deel word (Rousseau, 2010:184).

Dit is 'n gegewe dat gelowiges waarlik nuut in Christus is, maar dit is egter ook onbetwisbaar dat niemand in hierdie lewe ooit totaal nuut is nie (Hoekema, 1996:74) - daar is altyd 'n moontlikheid dat iemand vleeslik kan optree, dit wil sê kan sondig (Rousseau, 2010: 116). Die kwessie van ongeestelike/vleeslike handelswyse is juis in die eerste Korintiërbrief ter sprake: die apostel konfronteer die skuldiges daarmee dat hulle soos nie-Christene, dit wil sê vleeslik, optree (MacArthur, 2000:107). Paulus bestempel die Korintiërs nie as vleeslike gelowiges nie, maar stel dat hulle doen en late vleeslik is. Hy sê derhalwe nie, soos dit geïnterpreteer word, dat daar verskillende klasse mense en Christene is nie (MacArthur, 2000:107). Paulus moedig die Korintiërs dus nie aan om "geestelik" te word nie (vgl. MacArthur, 2000:107), maar herinner hulle daaraan dat dit hulle nie aan 'n enkele genadegawe ontbreek nie (1 Kor. 1:7, 30), en dat hulle gevolglik alles besit om reg te kan leef. Dit is verkeerd vir ' $n$ gelowige om anders te leef as wat hy in Christus behoort te wees (vgl. ook Ef. 5:8).

In die Romeinebrief, wat die duidelikste oproep tot lewensheiliging aan gelowiges rig, is daar geen verwysing na vleeslike gelowiges

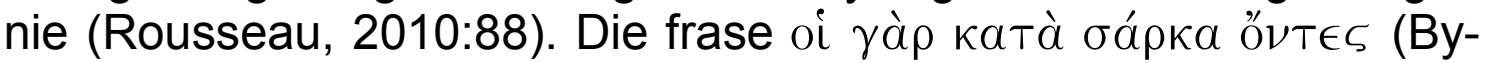
bel, 1988; Rom. 8:5: "Die wat hulle deur die sondige natuur laat beheers" - Bybel, 1983), word deur die piëtisme meestal verklaar asof dit na vleeslike gelowiges verwys. Dit is eksegeties nie korrek nie, omdat dit op mense dui wat nog nie Christene geword het nie (Song, 1998:250). 


\subsubsection{Die doop deur en met die Heilige Gees}

Laastens word kortliks gelet op die doop deur en met die Heilige Gees. Sonder hierdie noodsaaklike, opvolgende genadewerk (die doop met ...) het daar inderwaarheid - volgens so 'n leer - weinig gebeur. Die wedergeboorte was net die begin van die nuwe lewe en volgens so 'n leer is dit boonop 'n slegte begin. Dit blyk uit Coetzee (s.a.:11.73) se stelling dat wanneer die sonde algeheel en permanent uit die gelowige se gees verwyder is, sy "hart gereinig" is. So 'n gelowige is eers geskik om deur die Heilige Gees vervul te word wanneer "die doop met die Heilige Gees" gelyktydig met die verwydering/heiligmaking plaasvind. Hierdie proses word duidelik onderskei van "die doop deur die Heilige Gees (1 Kor. 12:13), wat by redding plaasvind" (Coetzee, s.a.:11.73). 'n Gelowige wie se hart só gereinig is en wat die doop met die Heilige Gees ondervind het, is posisioneel volmaak (Coetzee, s.a.:11.74) - hy het werklike heiligmaking ontvang in 'n sogenaamde "tweede genadewerk".

Hierdie siening word ten regte deur König (2006:126-127) verwerp in sy stelling dat die term die doop met die Heilige Gees 'n tegniese term is vir die Pinkstergebeure in Handelinge 2 (König, 2006:127). Hierdie feit staan direk teenoor die gemelde siening dat die term met hartsreiniging te doen het. Die "doop met" verwys in geen opsig na 'n latere, bykomstige, individuele mistiese/religieuse ervaring wat die bekering opvolg nie (König, 2006:127). Die eenmalige gebeurtenis van die koms van die Heilige Gees wat in Handelinge 2 opgeteken is, word egter so getipeer. Coetzee (s.a.:11.73) dui egter korrek aan dat die doop deur die Heilige Gees in 1 Korintiërs 12:13 op die bekering dui en dat dit vir alle mense geld "of ons slawe is of vrymanne, Jode of Grieke" (Bybel, 1999) wat in Christus deel van sy gemeente is. Hierdie waarheid kan ewe goed verwoord word soos dit in die NAV (1983) gestel word: "Omdat ons almal een liggaam geword het, is ons almal met die een Gees gedoop". Op grond van hierdie gegewens kan afgelei word dat die doop in die dood van Christus (Rom. 6:3 e.v.) deur die Heilige Gees plaasvind. Deur die doop in sy dood het gelowiges ook deel in sy lewe op grond van Christus se opstanding (Rousseau, 2010:87).

Deur die Heilige Gees se herskepping, deur die wedergeboorte, en deur die deel in die lewe op grond van Jesus se opstanding, doen en gee God alles wat nodig is vir die proses van voortgaande lewensheiliging waarmee $\mathrm{Hy}$ in ons lewe begin het. Tereg kan gevra word: "Watter hoër 'standaard' as Christus se opstanding-lewe kán daar [vir gelowiges] wees?" (vgl. Rousseau, 2010:87). 


\subsection{Stimulus vir ondersoek oor die second blessing}

Die eerste outeur van hierdie artikel is 'n lid van 'n kerkgenootskap waarin die leer van die second blessing verkondig word en het as 'n 25 -jarige tot bekering gekom. Na sy teologiese opleiding en 'n kort tydperk van gemeentebediening het hy 24 jaar lank teologie bestudeer en gedoseer. In kontak met studente tydens klassituasies en omgang met lidmate in sy kerk, het hy te doen gekry met talle kwelvrae wat ondervind word oor die leer van die vereiste second blessing. Terwyl hy hierdie leer aanvaar het, het hy die leer aan die hand van die Skrif ondersoek en besin oor die talle knelpunte daarin, asook die manier waarop die leer uitgeleef is deur sommige voorstanders en verkondigers daarvan.

In die lig van die voorafgaande bespreking en die eerste outeur se ervaring oor die leer van die tweede genadewerk, is die navorsingsvraag wat in hierdie artikel aan die orde kom die volgende: Wat is aanhangers van die leer van die tweede genadewerk se belewing van die fenomeen? Die motivering vir hierdie navorsing was dat dit moontlik sal aandui in hoe 'n mate die deelnemers se belewing in ooreenstemming is met die leerstellings van die leer, en in hoe ' $n$ mate dit teenstrydig is met die Skrif. Die resultate kan ook 'n aanduiding gee van moontlike kritiese aspekte in die bediening van sodanige persone, indien hulle leiding in hierdie verband versoek.

\section{Metateoretiese perspektiewe}

\subsection{Doel van die metateoretiese navorsing}

Die doel van hierdie navorsing was om vas te stel hoe aanhangers van die leer van die sogenaamde second blessing hierdie leer beleef.

Hierdie doelstelling is verder in 'n vierledige doelstelling verdeel, naamlik om vas te stel:

- op watter wyse iemand 'n aanhanger van hierdie vorm van piëtisme word;

- waarom iemand nie 'n aanhanger van hierdie vorm van piëtisme word nie;

- waarom iemand by hierdie leer sal bly; en

- op watter wyse iemand uit hierdie vorm van piëtisme "bevry" kan word. 


\subsection{Navorsingsontwerp}

'n Kwalitatiewe navorsingsontwerp, en meer spesifiek, 'n narratiewe analise, is gebruik (vgl. Lieblich et al., 1998:12; Berg, 2007:2), aangesien hierdie navorsing oor die persoonlike belewenis van 'n religieuse fenomeen en dogma handel.

Die konsepte vertelling (narratief) en lewenstorie ("life story") beklee tans ' $n$ belangrike plek in die sosiale wetenskap (Lieblich et al., 1998:1). Aangesien die mens van nature 'n storieverteller is (Lieblich et al., 1998:7) en taal 'n baie belangrike deel van kommunikasie met mekaar uitmaak (Anderson \& Goolishian, 1988:377), is dit wat mense oor hulle belewenisse vertel een van die duidelikste maniere om identiteit en persoonlikheid te ontdek (Lieblich et al., 1998:7).

\subsection{Deelnemers}

Die persone wat by die navorsing betrek is, is lank aanhangers van hierdie vorm van piëtisme. Almal was lede van dieselfde denominasie binne die breë lyn van die "evangeliese" heiligheidsbeweging. Hulle is volgens De Vos et al. (2003:79) "insiders" wat die tersaaklike fenomeen eerstehands ervaar.

Die deelnemers is deur die eerste outeur geïdentifiseer tydens informele gesprekke waarin die betrokke vorm van piëtisme ter sprake gekom het. Die groep deelnemers kan daarom beskou word as 'n doelgerigte steekproef (Neuman, 2000:198).

Drie groepe deelnemers van drie persone elk is gekies, naamlik mense wat in hulle kerk die dogma van piëtisme aanvaar en hulle as aanhangers daarvan beskou (huidige $p$-persone); diegene wat hierdie leer laat vaar het (gewese $p$-persone); en persone wat aktiewe aanhangers van hierdie piëtistiese stroming is, maar nogtans nie deur hierdie vorm van die piëtisme beïnvloed is nie (nooit p-persone nie).

Inligting oor die deelnemers (uiteraard word skuilname gebruik om anonimiteit te verseker):

\section{- Huidige p-persone}

Allan is 'n 70-jarige pensioenaris. Hy het op 41-jarige leeftyd tot bekering gekom. Kort daarna verlaat hy en sy gesin hulle vorige kerkverband. Sedertdien is hulle aktiewe lidmate van hulle huidige kerk.

Andrew is 51 jaar oud. Hy kom as agtienjarige tot bekering en kort daarna begin hy teologie bestudeer, eers by ' $n$ evangeliese Bybel- 
kollege en daarna ontvang hy teologiese opleiding by sy kerk se kweekskool.

Graham is 45 jaar oud. Hy het as elfjarige seun tot bekering gekom. Ongeveer tien jaar gelede betree hy die bediening en sedertdien het hy verskeie gemeentes bedien.

\section{- Gewese p-persone}

Edgar is 42 jaar oud en het as sestienjarige seun tot bekering gekom. Hy is vir die afgelope dertien jaar 'n predikant en is tans besig met nagraadse studie.

Marko is 47 jaar oud en het laat in sy twintigerjare tot bekering gekom. Daarna ontvang hy teologiese opleiding by verskillende instansies en is die afgelope veertien jaar reeds predikant. In sy nagraadse studie fokus hy op hermeneutiese aspekte.

Robert is 37 jaar oud. Hy het as negentienjarige tot bekering gekom. Ongeveer tien jaar gelede verlaat hy 'n suksesvolle loopbaan om teologie te bestudeer.

\section{- Nooit p-persone nie}

Amanda het twintig jaar gelede in haar vorige kerk tot bekering gekom en tien jaar later word sy 'n lidmaat van haar huidige kerk. In die verskeie gemeentes waar sy lidmaat was, het sy altyd toegewyd meegelewe.

Christopher is 46 jaar oud. Hy het as 'n vyftienjarige seun in sy vorige kerk tot bekering gekom. Hy is nou tien jaar lank lidmaat en na sy teologiese opleiding bedien hy die afgelope vyf jaar ' $n$ gemeente. Hy is besig met nagraadse studie.

Stephen is 64 jaar oud en het op sestienjarige leeftyd tot bekering gekom. Hy het ook, soos hy dit uitdruk, "in die kerk grootgeword". Op 'n betreklik vroeë stadium in sy lewe het hy 'n predikant geword.

Uit bogenoemde gegewens blyk dat sewe van die deelnemers predikante is en slegs twee lidmate. Die feit dat by die keuse van deelnemers, lidmate se insette nie breër betrek is nie, kan moontlik as 'n leemte in die navorsing aangevoer word. Aangesien daar egter 'n mate van sensitiwiteit aan die navorsing verbonde was, was dit wenslik om deelnemers so ver moontlik te beperk tot persone van wie dit verwag word om die leer te verkondig. 


\subsection{Data-insameling}

Tydens die eerste fase van data-insameling is die geïdentifiseerde persone telefonies genader om te verneem of hulle bereid sou wees om aan die navorsing deel te neem. Tydens hierdie gesprek is die begrip piëtisme in verband met die leer oor opvolgende genadewerke (die sogenaamde second blessing) verduidelik, asook die aard en doel van die navorsing. Die deelnemers moes aandui tot watter kategorie proefpersone hulle behoort.

Tydens die tweede fase het die deelnemers 'n semigestruktureerde vraelys (Neuman, 2000:260) ingevul. Die vraelyste is elektronies aan die deelnemers versend. Die vrae het die volgende aspekte aangeraak:

\section{- Huidige p-persone}

- Op watter wyse het u betrokke geraak by die piëtisme?

- Hoe het $\mathrm{u}$ die betrokkenheid by die piëtisme beleef (m.a.w. hoe het $u$ daaroor gedink en gevoel)?

- Sal u ooit hierdie leer versaak en terugkeer na die oorspronklike bybelse siening? Indien nie, waarom nie? Indien wel, waarom?

\section{- Gewese p-persone}

Die eerste twee vrae wat aan die huidige p-persone gevra is, is ook ter aanvang gevra.

- Hoe het dit gebeur dat u van die piëtisme af wegbeweeg het terug na die oorspronklike bybelse siening?

- Hoe het u die wegbeweeg van die piëtisme af terug na die oorspronklike bybelse siening beleef?

- Hoe kan mense wat so 'n lewenswyse aanhang, gehelp word?

- Nooit p-persone nie

- Waarom reken u raak mense aanhangers van die piëtisme?

- Waarom bly sommige mense aanhangers van die piëtisme?

- Waarom breek sommige mense daarvan weg? Hoe kry hulle dit reg?

- Hoe kan mense wat hierdie lewenswyse aanhang, gehelp word? 
Tydens die derde fase het die eerste outeur semigestruktureerde onderhoude (Poggenpoel, 2003:148) met elke deelnemer gevoer. Die onderhoude is met die toestemming van die deelnemers opgeneem (Poggenpoel, 2003:147), op oudiobande oorgeklank en getranskribeer. Sodoende het die eerste outeur goed met die data vertroud geraak, wat die analiseringsproses vergemaklik het (Braun \& Clarke, 2006:87). Dit het ook die geloofwaardigheid van die studie verhoog (Botes, 2003:180).

Tydens en na afloop van die onderhoude is sekere belangrike aspekte deur die eerste outeur van hierdie artikel aangeteken, naamlik:

- emosionele nuanserings en lyftaal van die deelnemers;

- die onderhoudvoerder se belewing van die onderhoud; en

- moontlike sterk- en swakpunte van die onderhoud (Neuman, 2000:277; Poggenpoel, 2003:147).

Die gemiddelde tydsduur van elke onderhoud was 45 minute.

\subsection{Data-analise}

Die tipe narratiewe analise wat tydens die data-ontleding gebruik is, was 'n kategoriale-inhoudsperspektief (categorical-content perspective) (Lieblich et al., 1998:16-17, 112) - ook bekend as inhoudsanalise.

Tydens die deurlees van die data is alle inligting geïdentifiseer wat by die navorsingsvrae aansluit, om sodoende die nuwe subteks vir verdere ontleding te word. Tydens die herhaaldelike lees van die vraelyste, die prosesnotas en die getranskribeerde onderhoude, asook die herhaaldelike luister na die oudiobande, het die eerste outeur van hierdie artikel temas en verbandhoudende aspekte/subtemas geïdentifiseer en opgeteken. Dit was 'n tydsame, sikliese proses waarin temas en verbandhoudende aspekte/subtemas telkemale gewysig is namate daar tot nuwe insigte gekom is.

Analise en interpretasie van die getranskribeerde teks is ook deur die tweede outeur van hierdie artikel gedoen. Dit, asook die onderskeie metodes waarop die data ingesamel is, het verseker dat 'n triangulasieproses gevolg is wat belangrik is vir die vertrouenswaardigheid (trustworthiness) van die navorsing (Botes, 2003:181).

Vervolgens is spesifieke uitsprake wat bekom is onder elkeen van die voorgestelde temas en verbandhoudende aspekte/subtemas ge- 
groepeer. Hierdie proses is deur die tweede outeur gekontroleer. Ten slotte is die oorspronklike data weer gelees en is besluit of die bevindings wat daaruit voortgekom het, 'n getroue weergawe is van die deelnemers se narratiewe oor die betrokke vorm van piëtisme.

\subsection{Etiese aspekte}

Tydens die navorsingsproses is streng gehou by die voorskrifte vir etiese navorsing (vgl. Neuman, 2000:486-491; Berg, 2007:78-82). Die doel en die navorsingsproses is aan die deelnemers verduidelik; deelname aan die projek was vrywillig en anoniem; deelnemers was vry om in enige stadium aan die ondersoek te onttrek; deelnemers het toestemming verleen dat die navorsingsresultate onder 'n skuilnaam gepubliseer kan word; en deelnemers is genooi om die inligting te kontroleer voordat dit in die navorsingsresultate gepubliseer sou word - hoewel geeneen dit opgevolg het nie.

\section{Resultate en bespreking}

Die deelnemers was deurgaans gretig om hulle volle samewerking vir die navorsingsproses te gee. Die temas, soos verkry uit die navorsingsdata, word in vier hoofpunte aangebied om sodoende 'n prosesmatige beeld te bied wat ooreenstem met die vierledige doelstelling van die empiriese ondersoek.

Deelnemers se narratiewe het talle opvallende ooreenkomste vertoon, en daarom word net enkele tersaaklike verbatim-aanhalings gebruik. Daar is gepoog om deelnemers naastenby ewe veel aan die woord te stel.

\subsection{Hoe raak iemand by hierdie vorm van piëtisme betrokke?}

Die huidige p-persone en die gewese p-persone se belewing is veral by hierdie aspek ter sprake. Waar relevant, word insette van die nooit p-persone nie, ook vermeld.

Die deelnemers wat in die eerste twee kategorieë val, is meelewende lidmate van hulle kerk. Almal is predikante, behalwe een deelnemer wat as 'n ouderling dien.

\section{- Tema 1: Kerkverband}

Soos verwag kan word, is die eerste tema kerkverband. 'n Verbandhoudende aspek, naamlik dogma, vloei daaruit voort. Dit is te verstane dat lidmate dít wat in hulle genootskap verkondig word, as die ware leer sal aanhang. Robert sê dat hy in sy kerk "grootgeword" 
het, en geen ander kerk en dogma ken nie. Allan het nadat hy tot bekering gekom het, 'n lidmaat van sy kerk geword. Graham het vanaf ' $n$ vroeë stadium in sy lewe (as elfjarige) met die betrokke vorm van piëtisme te doen gekry toe sy ouers lidmate van sy kerk geword het en hy self ook kort daarna in die kerk tot bekering gekom het. Andrew en Edgar het albei ná hulle bekering die kerk begin besoek, dadelik daarby aanklank gevind en lidmate geword. Marko het die eerste keer in sy kerk met hierdie vorm van piëtisme te doen gekry, maar hy weet ook van ander kerke en bewegings waarin die leer van opvolgende genadewerke voorgehou word.

\section{- Tema 2: Tweede genadewerk}

Die leer van die tweede genadewerk (of dit wat verkondig word), sluit aan by die kerkverband, en die deelnemers is almal in hulle eie kerk tot hierdie vorm van piëtisme beweeg. Behalwe dat dit prominent in die algemene Woordverkondiging figureer, dui Marko aan dat die leer van 'n opvolgende genadewerk veral by sy kerk se konferensies beklemtoon word. Robert het by so 'n konferensie 'n "oorgawe gemaak" om die genadewerk te ontvang.

'n Verbandhoudende aspek by die verkondiging van die tweede genadewerk, is die ervaring daarvan. In Andrew se geval was dit positief: hy het by die kweekskool van sy kerk aangevoel dat die Here hom "bekragtig" het. Dit het by 'n toewydingskonferensie met die aanvang van sy studie gebeur. In daardie stadium het hy sy godsdiens as "kragteloos" ervaar en tydens die konferensie het hy die rede daarvoor gesoek. Hy het oortuig geraak dat hy die verkeerde dinge wat hy aan ander gedoen het, sal moet regmaak "voordat die Here die werk vir my sal doen". Allan sê dat daar by hom as 'n jong bekeerling. "'n begeerte en strewe was om rein te lewe. Toe daar aan ons vertel is dat daar iets soos ' $n$ volheidslewe is, ' $n$ tweede genadewerk wat moet plaasvind na jou redding, het dit ons aangegryp."

Ander se ervaring was egter negatief. Robert het by 'n konferensie homself verbind om die second blessing te ontvang. Dit was vir hom opvallend dat feitlik niks in sy lewe verander het nie: "[dit was] nie geweldig anders as wat dit was voor die tyd nie - maar ek het die 'ondervinding' gehad!" Hy was teleurgesteld en sê dit was vir hom "amper [soos om] God se guns te verdien". Daarna het dit hom so na antwoorde vir sy baie vrae laat soek dat hy van die Here vervreemd geraak het. Later het hy besef "die Skrif is uit verband geneem" en hy het "vertroue verloor in die kerk en die manier van interpretasie van die Skrif". 
By albei opleidingsinstansies waar Marko studeer het, is die leer van opvolgende genadewerke baie ernstig beklemtoon en hy het vanweë "al daai vrae en vertwyfeling" baie druk ervaar. Sy negatiewe ervaring het veral by die tweede opleidingsentrum vererger waar die groepsdruk deur mense wat oor die genadewerk getuig het, veroorsaak het dat hy minderwaardig gevoel en baie onsekerheid beleef het omdat "ek [nie] kan saampraat nie". Dit het veroorsaak dat hy aan skuldgevoelens begin ly het en "ek het aan my redding begin twyfel ... en in onsekerheid gelewe vir baie lank". Allan meld dat die leer behels dat gelowiges "'n Kanaänlewe ... moet deelagtig word om sodoende van die ou mens, die inwonende sonde, verlos te kan word". Hy is baie verwar deur die leer, maar het dit aanvaar.

Die negatiewe ervarings raak ook mense wat nie hierdie vorm van piëtisme aangehang het nie. Christopher het beleef dat piëtiste "jou [laat] voel daar moet iets met jou fout [wees] ... dit laat 'n mens baie verneder voel"; en Stephen het gevoel dat hy nooit die "standaard" kan bereik wat verkondig word nie.

\section{- Tema 3: Onkunde}

'n Derde faktor wat mense piëtistiese aanhangers kan laat word, is onkunde. Die deelnemers, uitgesonderd een gewese p-persoon wat in die kerk grootgeword het, verklaar dat hulle óf baie min, óf niks van die Bybel geweet het, maar vervul was met entoesiasme om die Here met oorgawe te dien.

'n Oorsaak van onkunde kan godsdienstige onbetrokkenheid wees. Allan en sy gesin het as lidmate van hulle vorige kerk byna nooit kerk toe gegaan nie en dit het meegebring dat hulle baie min van die Bybel en godsdiens geweet het. Dit was ongeveer dieselfde geval met Edgar wat tot met sy bekering nooit in 'n kerk gekom het nie. Hy sê dat hy niks van die Bybel geweet het nie. Toe Edgar asook Allan en sy gesin by hulle huidige kerk lidmate geword het, het hulle aanklank gevind by die piëtistiese vorm van godsdiensbeoefening. Stephen is oortuig dat "dit uitsluitlik onkunde [is]" wat mense in sy kerk by die piëtistiese vorm van godsdiensbeoefening betrokke laat raak.

Onkunde beïnvloed nie net lidmate nie, maar ook predikante. Allan het as gevolg van sy eie en moontlik sy predikant se onkunde "baie frustrasie belewe", want "[e]lke keer as so 'n boodskap gepreek is [oor die tweede genadewerk], was die hoop daar dat ons miskien nou alles sal verstaan ... maar daar was net nooit volkome verlossing van die inwonende sonde nie". 
Stephen kritiseer die kweekskool van sy kerk wat 'n sekere generasie predikante nie opgelei het om hermeneuties met die Skrif om te gaan nie. Hy stel die volgende: "nooit, nooit ... op kweekskool [het ek] die gereedskap gekry om die Skrif te ondersoek of te verklaar of te interpreteer nie". Leraars se onkunde benadeel gevolglik die lidmate en hy vra "hoe kan jy aan iemand anders verkondig wat jy self nie het nie?"

'n Eerste verbandhoudende aspek met onkunde is naïwiteit. Dit behels eerstens die naïwiteit van lidmate ten opsigte van predikers en hulle hantering van die Skrif. In hierdie verband vermeld Robert dat predikante in sy kerk die meeste van die tyd beskou word as bo kritiek verhewe, want "daar was vir jou geleer van kleins af die gesalfde van God raak jy nie aan nie, jy praat nie van die ou nie, jy sê niks van hom nie, al wat jy moet doen, is jy moet luister". Edgar sê: "Naïwiteit is 'n verskriklike gevaarlike ding en piëtisme hou ouens naïef ... die wêreld van 'n piëtis is eintlik 'n baie lekker wêreld ... in daai wêreld is alles veilig ... is alles 'cut and dried'". Stephen beskou lidmate se naïwiteit as 'n bepalende faktor vir hulle betrokkenheid by piëtisme: "mense het 'n baie hoë dunk van predikante en wat hulle sê is evangelie". Vanweë onkunde kan lidmate nie self die Skrif ondersoek nie, dus "hoor hulle maar" wat verkondig word en aanvaar dit onnadenkend, want "dit klink of dit sin maak, want die voorgangers ... dis met oorgawe wat hulle dit verkondig".

Naïwiteit is ook 'n belangrike faktor by die opleiding van leraars. Ofskoon Marko se leermeester tydens sy opleiding nie bevredigende antwoorde op sy vrae oor die tweede genadewerk kon verstrek nie, het hy dit wat vir hom gesê is, maar "aanvaar as komende van my meerderes, ouens wat al baie meer ervaring en kennis as ek het, en miskien is hulle reg". Hy het later egter besef dat hy self die dinge nie deurdink het nie: "Ek dink 'n mens eet maar alles soos soetkoek op." Graham het 'n soortgelyke uitspraak gehad.

Onkunde en naïwiteit hou tweedens ook verband met entoesiasme. Veral pasbekeerde mense en nuwe lidmate kan deur hierdie entoesiasme meegevoer word. Graham was kort nadat hy op elfjarige ouderdom tot bekering gekom het, baie beïndruk deur die verkondiging van die "Egipte, die woestyn- en Kanaänlewe van die volk Israel ... en ek het per geleentheid die Here vir 'n 'rein hart' of tweede genadewerk vertrou". Edgar se storie bied ook 'n voorbeeld van entoesiasme: hy was as 'n sestienjarige kort na sy bekering "so uitverkoop [besiel] aan die Here, 'n Jehovah-getuie kon aan my enige ding verkoop het". Omdat hy so geesdriftig was om reg te lewe "sou [ek] in Checkers loop en koortjies [geestelike liedere] hardop sing ... 
ek het gedink dis wat ek moet doen". Christopher beskryf die doel van sy entoesiasme soos volg: "[om] die Here te behaag ... om meer en beter Christen te wees".

Onkunde kan ook by mense voorkom wat godsdienstig aktief is en die Bybel gereeld lees. Amanda is oortuig dat iemand se onwilligheid om die Bybel intelligent te lees of dit eksklusief te lees, te blameer is vir sy/haar onkunde. Dit sluit aan by Robert se stelling dat mense die Bybel vanuit 'n bepaalde konteks "verstaan" of lees, en gevolglik nie reg kan verstaan nie.

Mistisisme is 'n derde aspek wat verband hou met onkunde. Amanda skryf eksklusivisme ten opsigte van die lees van die Bybel en derhalwe die onkunde daaroor toe aan die mistiese standpunt wat vele huldig, naamlik "die Heilige Gees kan hulle [gelowiges wat so met die Skrif omgaan] alleen die insig [in die Skrif] gee". Robert staan baie krities teenoor die mistisisme en sê dat mense ander daardeur manipuleer: "[l]emand vir wie daar in die Skrif 'n gedeelte 'oopgegaan' het en hy sodoende mense se aandag wil kry ... gebruik dit as 'n metode om mense te manipuleer". Hy verwys na iemand wat sê "die Here het vir my gesê" en dan praat die persoon van iets soos dat hy oortuig gevoel het om 'n spesifieke plastiek wasbalie te koop. Robert meen mense doen dit om "voor 'n gehoor geestelik te klink ... maar as jy saam met die persoon begin lewe, dan kom jy agter iewers is daar 'n probleem, ... daar's fout in sy lewe - ook met sy optrede teenoor mense".

'n Vierde verbandhoudende aspek met onkunde, is tradisie. Gehegtheid aan tradisie laat mense navolgers word van die leer van die piëtisme. Amanda meen "hierdie mense is oningelig, want hulle weier om ander mense se sieninge ook te lees en hulle bly oningelig". Sy meld dat "hierdie tradisie ... vir hulle belangriker [raak] as die Woord ... die groot probleem hier is TRADISIE, 'n vloekwoord!" Sy meen verder dat mense se sienswyse van "ons doen dit dan nou al soveel jare so, wat is dan eintlik verkeerd? ... het al vele gemeentes laat skeur en mense weggedryf".

\section{- Tema 4: Standaard}

Die vierde tema, naamlik 'n sekere standaard van lewensheiligheid waaraan gelowiges moet voldoen, figureer prominent in die leer van die piëtisme. Christopher bring die sogenaamde Kanaänlewe in verband met die standaard van heiligmaking wat verkondig word en sê: "Daar moet 'n persepsie wees dat die standaard wat gehoorsaam moet word, God se standaard is, maak nie saak of daardie 
persepsie geldig is of nie." Amanda meen die standaard is deur mense daargestel en Christopher verduidelik dat wanneer iemand volgens sy/haar persepsie in ooreenstemming met die standaard optree, dan bewerk "die gehoorsaamheid aan hierdie standaard ook die salige gevoel van sekerheid van saligheid - godsdiens word nou 'n gevoel wat die piëtis ervaar".

'n Aspek wat met uiterlike dinge verband hou, vorm ook deel van die piëtistiese standaard wat verkondig word. Vrouelidmate word veral veroordeel. Edgar maak die volgende stelling: "hierdie sogenaamde heiligheidsleer het baie sterk gefokus op uiterlike sonde ... ek was uitverkoop gewees dat 'n vrou nie 'n langbroek mag dra nie ... grimering is sonde, ek het dit geglo, ... ek het tot my meisie aangespreek as sy dit gedoen het". Ofskoon mense die standaard handhaaf, het Amanda gevind dat diegene wat dit so rigied doen, nie eg is nie: "Hierdie geweldige, kan ek sê heilige, skoon mense ... dit wat jy sien is nie werklik wat hulle altyd is nie". By Robert het 'n verset onstaan teen die gewoonte om vroue altyd negatief te teiken "terwyl daar nooit na die manne verwys is nie". Marko beaam die feit: "Die arme vrouens het vreeslik slae gekry op die konferensies en die manne het altyd ongeskonde daarvan afgekom."

Dit blyk dat mans egter ook soms "getoets" is aan die standaard wat gestel is. Robert vertel van 'n jeugkamp waar die persone in beheer tot groot vermaak van ander jongmense gespot het met jong mans omdat hulle 'n haardroër gebruik het: "Amper 'n tipe van ding dat as jy 'n haardroër gebruik, dan is jy eintlik nie 'n kind van God nie ... dan is jy eintlik skeef [homoseksueel]". Edgar verwys na die houding aan die kweekskool waar hy gestudeer het: "Jy is heeltyd veroordeel, jou hare is te lank ... jy mag nie eers 'n kortbroek op die terrein gedra het nie".

\subsubsection{Samevatting}

Die data bevestig dat 'n piëtistiese dogma oor die vereiste van opvolgende genadewerk prominent in die deelnemers se kerkverband figureer en deel van die kerk se tradisie is. Die genadewerk word in die verkondiging beklemtoon om die standaard wat vir heiligmaking gestel word, te kan bereik. Lidmate raak dikwels by 'n vorm van piëtisme betrokke vanweë onkunde. Hierdie onkunde en die tradisie beïnvloed selfs die opleiding van leraars. Die tradisionele standaard wat by heiligmaking voorgehou word, handel meestal oor uiterlike dinge en dit is veral vrouelidmate wat aan so 'n heiligheidstandaard moet voldoen. Ofskoon sommige deelnemers piëtisme as dogma positief ervaar, het ander 'n uiters negatiewe ervaring daarvan. 
In hierdie stadium kan gestel word dat die leer van die opvolgende genadewerk nie skriftuurlik verantwoord is nie, want die leer is onversoenbaar met die Skrifopenbaring oor die algenoegsaamheid van Christus, die versoening, en die werk van die Heilige Gees. Op grond van die terugvoer van deelnemers is dit duidelik dat die strewe na heiligmaking by individue aanwesig is, maar die kerk as die eenheid waarin die Heilige Gees werksaam is, word nie vermeld nie. Die beklemtoning van die individu se verantwoordelikheid wat in die leer van die opvolgende genadewerk uitstaan, misken die belangrikheid van die gemeente as geloofsgemeenskap waarbinne die Heilige Gees as Heiligmaker werksaam is.

Die beklemtoning dat elke individu 'n tweede genadewerk moet ervaar, het tot gevolg dat gelowiges vanweë onkunde piëtisme as vorm van godsdiensbelewing kan aanhang. Die Skrifgegewens oor sonde en heiligheid word dikwels nie aan lidmate gekommunikeer nie. Hierdie toedrag van sake spruit onder andere voort uit die opleiding van leraars waarin piëtisme, as godsdiensbelewing en tradisionele verkondigingsinhoude, as baie belangrik geag word. Die leer van die tweede genadewerk het ook 'n negatiewe uitwerking op gelowiges se uitlewing van die liefdesgebod teenoor hulle naaste, wat in stryd is met die bybelse voorskrifte daarvan.

\subsection{Waarom iemand nie by hierdie vorm van piëtisme betrokke raak nie}

Die uitsprake van die nooit p-persone nie is in hierdie afdeling van die artikel ter sprake, hoewel toepaslike insette van deelnemers in die ander twee kategorieë ook gebruik is.

Al die deelnemers, uitgesonderd Amanda, is dienende leraars in hulle kerk waarin die verskynsel van piëtisme voorkom. Amanda is 'n aktiewe lidmaat in 'n leidende posisie by haar kerk. Ofskoon die deelnemers nie die leer van die opvolgende genadewerk aanvaar, nastreef en verkondig nie, beleef hulle hul geloofslewe as vervullend, en hulle bediening voldoen aan al hulle verwagtings.

\section{- Tema 1: Kerkgenootskap waarbinne iemand tot bekering kom}

Amanda en Christopher het in hulle vorige kerke (altwee gereformeerde instellings) tot bekering gekom voordat hulle in hulle huidige kerk met piëtisme te doen gekry het. Dit het meegebring dat hulle nie by piëtisme as godsdiensbelewingsvorm in die huidige kerk betrokke geraak het nie. 


\section{- Tema 2: Die wyse waarop piëtisme uitgeleef word}

'n Tweede tema is die wyse waarop piëtisme uitgeleef word. 'n Verbandhoudende aspek hiermee is gesindhede. Persone wat die leer sterk ondersteun en ook bely het dat hulle 'n "tweede" genadewerk ontvang het, se optrede het Stephen baie gepla. Hy stel dit soos volg: "In my geval het ek onheilige gesindhede en optrede by talle sogenaamde heiliges opgemerk wat tot groot verwarring gelei het." Hy verwys na 'n amusante voorval tydens 'n genesingsdiens wat hy as jong gelowige bygewoon het: 'n groep predikante bid om die beurt vir mense wat sit en wag vir gebed. Hy het die verloop skelmpies dopgehou en gesien hoe persone plekke geruil het sodat ' $n$ sekere predikant nie vir ander sou bid nie en hy sê "die goed het nie vir my sin gemaak nie".

Stephen het as jong gelowige en later as teologiestudent bedag geraak op die foutiewe wyse waarop piëtisme uitgeleef word deur piëtistiese leraars en lidmate, vanweë hulle gesindhede teenoor ander mense. Hy sê-vra: "Hoe kan jy hom glo as hy op die kansel staan ... terwyl sy optrede van die kansel af alles behalwe Godvererend was?".

Ongeloofwaardigheid is ' $\mathrm{n}$ verbandhoudende aspek met die wyse waarop piëtisme uitgeleef word. Amanda sê in haar huidige kerk word baie oor 'n "standaard" van geestelikheid of heiligheid gepraat, maar sy het waargeneem dat die leraars wat dit verkondig en lidmate wat dit voorstaan, ongeloofwaardig is: "Volgens hulle is hulle hierdie 'Christene', maar ... dit wat jy sien, is nie werklik wat hulle altyd is nie". Marko sê: "Dieselfde mense wat so 'n verskriklike uiterlike vertoon maak ... van hulle dra baie preutse kleredrag en al daai soort van dinge, maar hulle hart is vol veroordeling en daar's nie liefde nie".

'n Derde verbandhoudende aspek met die wyse waarop piëtisme uitgeleef word, is reëls wat verkondig word. Dit sluit ook aan by die aspek van uiterlike dinge. Amanda beskryf die heiligmakingsreëls oor vroue se kleredrag en voorkoms as 'n "gepak". Sy het ondervind dat lidmate deur die "gepak" van haar huidige kerk af weggedryf is, en sy verwys na iemand wat "nie in die kerk wil sit en skuldig voel oor sy nie 'n hoed op het of sykouse aan het nie, of grimering; sy wil kerk toe kom om kos vir haar siel te kry ... die persoon het van gemeente verander omdat haar predikant 'n piëtis is".

'n Vierde verbandhoudende aspek met die wyse waarop piëtisme uitgeleef word, is onverdraagsaamheid. Christopher ervaar dat baie 
piëtiste die beskouing huldig dat God nie kan wag om iemand te straf wat - volgens hulle - verkeerd gedoen het nie. Volgens hulle hou God ander gelowiges met 'n "harde oog" dop. Marko het dit ervaar as "verskriklik wetties, verskriklik veroordelend, daar's nie by hulle 'n sagtheid en 'n liefde nie ... die vrug wat 'n mens werklik soek van die Gees ... dinge soos sagmoedigheid en vrede en die dinge, dis dinge wat ek net nie gesien het nie". Robert sê dat "'n geweldige skuldlas op mense gelaai word ... ek dink die klem het gelê op die vrees in plaas van die genade wat ons reeds ontvang het". Die onverdraagsame optrede van leraars wat so preek, het "naderhand begin om 'n weersin in my hart te wek" veral "as jy hoor wat hulle te sê het oor ander mense ... die haat wat baie keer in hulle hart na vore kom".

Dit blyk verder dat onverdraagsaamheid verantwoorde teologiese besinning aan bande lê. Edgar het ervaar dat hy tydens sy opleiding nie teologies eerlik oor die Bybel kon dink nie, want "die Bybel het mos uit die hemel uit geval, klaar geskryf ... God het die Bybel vir Moses gedikteer ... enige ou wat nie so gedink het nie, het 'n dwaalleer". Hy het in 'n vroeë stadium van sy opleiding "begin om wyer te lees, wyer te dink", maar is die swye opgelê deur sommige van sy leermeesters. Dit het die volgende meegebring: "In my eerste jaar [is ek] voorwaardelik oorgeplaas ... dat ek in my tweede jaar my bek sal hou ... jy mag nie dink nie, jy mag nie praat nie - dis stremmend, hierdie goed".

Die tradisie-aspek wat vroeër vermeld is, speel ook by onverdraagsaamheid 'n rol. As iemand nie met die tradisie saamstem nie, veroorsaak dit wrywing, selfs tot so 'n mate dat so iemand, volgens Christopher, as 'n "vyand van die kruis" uitgemaak sou word. Christopher meld dat aanhangers van die leer nie sal skroom "om so 'n persoon [wat verskil] weg te werk en karaktermoord te pleeg" nie. Volgens Christopher het teologiese voorgangers die Skrif in hulle uitleg "herskryf" om die betrokke dogma van die piëtisme te staaf en sodoende die tradisie in stand te hou. Marko sê: "Daar's roekeloos met sekere Skrifgedeeltes en allegorieë omgegaan om die punt van hartsreiniging behoorlik huis toe te dryf."

\subsubsection{Samevatting}

'n Grondige gereformeerde leer kan daartoe meewerk dat persone nie by piëtisme as vorm van godsdiensbeoefening betrokke raak nie. Persone wat na bekering in ' $n$ ander kerk lidmate was, is daarom nie deur die leer van hierdie vorm van piëtisme beïnvloed toe hulle van kerkverband verander het nie. Die ongeloofwaardige wyse 
waarop piëtisme deur aanhangers daarvan uitgeleef word, kan iemand daarop bedag maak en hom/haar daarvan weerhou. Die fundamentalistiese perspektiewe oor die Skrif en die handhawing van 'n tradisie, kortwiek dikwels verantwoorde teologiese denke.

Dit blyk dat die noodsaaklikheid van hermeneutiese integriteit jeens die Skrif, volgens hierdie deelnemers, deur sommige leraars verontagsaam word. Piëtistiesgesinde mense se onverdraagsame uitlewing van hulle geloof teenoor medegelowiges is ook nie in ooreenstemming met bybelse voorskrifte dat gelowiges mekaar moet liefhê nie.

\subsection{Waarom iemand hierdie vorm van piëtisme bly handhaaf}

Die inligting wat by die huidige p-persone en die voorheen p-persone bekom is, is veral in hierdie deel van die artikel ter sake. Deelnemers in die kategorie nooit p-persone nie, se hipotetiese insette was ook insiggewend en sal laastens afsonderlik bespreek word.

\section{- Tema 1: Sekerheid van die ervaring van die "tweede" genadewerk}

Die eerste tema is die sekerheid wat iemand aangaande die ervaring van die tweede genadewerk ervaar. Andrew is daarvan oortuig dat hy die tweede genadewerk ontvang het. Hy verduidelik dat hy tydens 'n konferensie by sy kerk se kweekskool in die gebedskamer "die aangesig van die Here gesoek het. Toe het daar dinge gebeur wat vir my gewys het ek moet eers 'n paar dinge in my lewe regstel as kind van die Here, voordat die Here vir my die werk sal doen. En ek het toe dit waarvan ek oortuig geraak het, reggestel en 'n stille versekering wat die Here in my hart gebring het ... Hy het dit bevestig".

Hy skryf die feit dat hy as predikant dien toe aan die genadewerk. Verder sê hy dat hy nie omgegee het vir sy lewe voordat hy die tweede genadewerk ontvang het nie, en gewis nie sy vorige lewe wil terughê nie.

\section{- Tema 2: Nie van iets anders oortuig nie}

'n Tweede tema is dat 'n persoon nie van iets anders oortuig is nie. Ofskoon Graham 'n mate van onsekerheid oor die dogma van 'n genadewerk koester en self al "gevoel het of 'n mens nooit daarby [die sondelose lewe] sou uitkom nie", aanvaar hy egter dat die kerk reg is. Die verbandhoudende aspek van lojaliteitgevoel sluit by hierdie tipe aanname aan. Graham is lojaal jeens sy kerk - hy wil nie die 
leer kritiseer nie en hy wil hom nie daarvan wegkeer nie, maar koester eerder die hoop dat "as die leer van die kerk verkeerd is, dan sal die Here ons tot die regte insig bring".

'n Tweede verbandhoudende aspek is dat iemand so in die geloofsgemeenskap gevestig geraak het, dat verandering baie moeilik sal wees. Robert is pessimisties oor die moontlikheid dat mense wat die leer baie sterk voorstaan, tot verandering oorgehaal kan word. Hy sé: "oortuig gaan jy hulle nie oortuig nie", maar hy glo desnieteenstaande dat indien die Heilige Gees iemand oortuig, dan kan hy vry raak. Edgar is ook uitgesproke daaroor: "So, ek wil regtig sê daar's ouens wat nie daar gaan uitkom nie, al stuur God 'n engel uit die hemel."

\section{- Tema 3: 'n Geslote godsdienssisteem}

Die derde tema is dat 'n piëtistiese beweging 'n geslote godsdienssisteem kan wees. Hier is die verbandhoudende aspek van tradisie weer ter sprake. Robert verwoord dit soos volg: "Dis baie makliker om te preek wat broer $A, B$, of $C$ gesê het ... tradisionele verkondiging is baie makliker en dis baie veiliger". Graham se belewenis tydens sy teologiese opleiding spreek ook hiervan, wanneer hy sê "' $\mathrm{n}$ ou is maar bekommerd, 'n ou is maar versigtig en ek dink dis maar deel van 'n ou se agtergrond dat ons geleer is dat ... jy bevraagteken nie ander ouens, 'groter mense' se sienswyse nie".

\section{- Tema 4: Positiewe ervarings}

'n Vierde tema is die positiewe ervarings wat gelowiges in 'n piëtistiese geloofsgemeenskap kan laat bly. Die eerste verbandhoudende aspek is dat iemand godsdienstige euforie kan beleef. Marko beskryf dit soos volg:

Jy's doer op die wolke, jy's op 'n geestelike vlak waar jy amper 'untouchable' is vir versoeking en daai tipe van dinge, so dit word ... dis eintlik 'n illusie wat geskep word, die spreekwoordelike 'pie in the sky' wat vir jou geskets word.

'n Tweede verbandhoudende aspek is die moontlikheid dat piëtisme iemand kan verslaaf. Marko stel dat baie gelowiges 'n "geestelike high" tydens die kerk se konferensies beleef. Hy vertel:

... daar word jy van vroeg vanoggend tot laat vanaand ... word jy gepréék ... ten minste vyf, ses byeenkomste per dag waar daar by elke boodskap baie sterk gepreek is, baie sterk uitnodiging gemaak word ... daar word soveel druk in daai konferensie gelaai ... 
Edgar vergelyk hierdie ervaring en die effek van hierdie soort godsdiensaktiwiteit met dwelmverslawing wat iemand van die realiteit kan vervreem. Dit bied ontvlugting aan mense en hy sê dat dit net soos vir 'n verslaafde "baie aangenaam is om op drugs te wees" en dit skep vir die mense wat daaraan verslaaf raak "'n wêreld wat nie regtig bestaan nie ... dis amper meer of iemand verslaaf is, op dwelms is ...".

'n Derde verbandhoudende aspek by positiewe ervarings is ' $\mathrm{g}$ gevoel van verhewenheid. Wanneer mense volgens hulle persepsie "bokant sonde leef", kan selfverheffing verwag word. Allan verwys na iemand wat meen hy is "so $70 \%$ soos Christus".

\section{- Tema 5: Negatiewe ervarings}

Teenoor die tema van positiewe ervarings staan die vyfde tema van negatiewe ervarings. Alhoewel Allan die leer van die piëtisme aanvaar het, het dit hom so gefrustreer dat hy moedeloos geraak het oor sy eie lewe. Hy het uiters minderwaardig gevoel, want hy kon eenvoudig nie kom waar ander sê hulle is nie. Marko het homself ook dikwels vergelyk met "ander ouens wat baie toegewyd lyk en baie vroom lyk en op die oog af nie die stryd ervaar wat jy ervaar nie ... en dan kom jy weer by die selfveroordeling, ek is net nie goed genoeg nie". Die uitwerking hiervan is dat iemand maar aanhou probeer met die hoop dat hy eendag wel die verkondigde vereiste standaard sal bereik.

Nooit p-persone nie het vanuit hulle bedieningsondervinding ook belangrike insette gelewer en hulle hipoteses word vervolgens bespreek.

Onverantwoorde Skrifgebruik kan mense aanhangers van die dogma van piëtisme maak, omdat sulke gelowiges aanvaar dat dit reg is. Volgens Christopher kan dit gebeur dat teologiese voorgangers selfs die Skrif "herskryf" om hulle dogma te dien. Die rede hiervoor, volgens hom, is: "Die ervaring word die dogma ... die ervaring van die individu verklaar wat die Skrif bepaal". Dit sluit aan by Robert se uitspraak dat die dogma meebring dat iemand die Bybel "uit 'n bepaalde konteks, uit 'n bepaalde verstaan" lees en gevolglik verkondig.

Die geslotenheid van die godsdienssisteem waardeur gelowiges nie blootgestel word aan 'n ander leer en tipe verkondiging nie, kan mense ook in piëtistiese godsdiensbeoefening laat volhard. Stephen is "van oortuiging dat mense nooit hiervan [piëtisme] sal loskom 
tensy hulle ander blootstelling ervaar nie". 'n Faktor wat hiertoe bydra, is mensevrees wat kan ontstaan weens die onverdraagsaamheid van piëtistiese leiers. Stephen meen dit "is die groot rede waarom sommige mense daarin volhard, dikwels teen hulle eie beterwete".

Die positiewe ervarings vind by piëtiste uiting in die verbandhoudende aspek van geestelike trots. Christopher verwys hierna as die "beter as jy"-gevoel en hy sê: "Hierdie gevoel word verslawend en bewerk 'n sin vir bestaansreg en goeie selfbeeld." Vanweë geestelike trots het hy van piëtistiese persone ervaar dat hulle vanuit die "gearriveerde posisie" hoogmoedig neersien op ander. Hy stel dit soos volg: "Hoe heiliger hierdie persoon word, hoe meer reg gee dit vir hom/haar om andere tereg te wys, te veroordeel, te verwerp en weg te jaag ... hulle dink dat hulle vir God 'n guns bewys". Hy het selfs ervaar dat piëtiste 'n "sadistiese vergenoegdheid" kan put uit die perfektheid wat hulle meen, hulle bereik het. Christopher beskryf hierdie optrede as "absoluut walglik".

\subsubsection{Samevatting}

Dit blyk dat iemand wat in die godsdienspatroon van die piëtisme gevestig is, moeilik sal verander. 'n Ervaring van die genadewerk wat verkondig word, kan meewerk dat iemand glo dat dit werklik bestaan. Gelowiges kan so in die geslote godsdienssisteem gevestig raak dat hulle nie ander godsdienstige invloede beleef nie. Positiewe ervarings laat gevoelens van godsdienstige verhewenheid en geestelike trots by persone ontstaan; maar negatiewe ervarings wat wel by sommige persone bestaan, veroorsaak dat iemand sal aanhou probeer om die ervaring van die verkondigde tweede seën te bereik. Die onverdraagsaamheid binne die geslote sisteem kan weens mensevrees ook meebring dat iemand die piëtistiese vorm van godsdiensbelewing nie aflê nie.

Die ervaring van 'n tweede seën kan nie die genadewerk bevestig nie. Tweedens sou 'n lojaliteitsgevoel jeens 'n kerk nie 'n onverantwoorde Skrifgebruik of die geslotenheid en tradisie van die geloofsisteem kan legitimeer nie. Indien piëtisme geïnterpreteer word teen die agtergrond van leefstylverslawing, is die uitwerking van godsdienseuforie, geestelike trots, en selfverheffing allermins met die Skrif te versoen. 


\subsection{Hoe iemand van hierdie vorm van piëtisme bevry kan word}

Die voorheen p-persone en die nooit p-persone nie stem in breë trekke saam oor hoe om van piëtisme bevry te word. Ofskoon huidige p-persone die dogma van die piëtisme aanvaar, bestaan daar selfs by hierdie deelnemers ook kritiek.

\section{- Tema 1: Die leer is nie hermeneuties getrou nie}

Die eerste tema is dat deelnemers besef dat die leer nie hermeneuties getrou is nie. Marko stel: "Daar is partykeer selfs roekeloos omgegaan met sekere Skrifgedeeltes en allegorieë om die punt van hartsreiniging behoorlik huis toe te dryf." Dit het Marko genoop om in die lig van die Skrif, krities oor 'n tweede genadewerk te besin. Hy het die Bybel aan die hand van die grammaties-historiese hermeneutiek waarin hy later onderrig is, verklaar, en ontdek dat die Skrif misbruik word om hierdie leer te staaf en dit het tot sy "vrymaking" gelei.

Die Egipte-Kanaänverhaal as 'n begronding vir die tweede genadewerk het vir Edgar as 'n jong gelowige "sin gemaak" en hy skryf dit daaraan toe dat toe hy tot bekering gekom het, was hy so onkundig oor die Bybel dat hy "nie eers geweet het wie Simson of Salomo was nie". Graham en Allan is eweneens as jong, onkundige gelowiges deur dieselfde verkondiging beïndruk.

Volgens Christopher is verantwoorde, wetenskaplik gefundeerde eksegese "onmoontlik versoenbaar" met die "onverantwoordelike" manier waarop die Skrif deur piëtistiese teologiese leiers en predikante "verstandelik herskryf" word om hulle dogma te dien. Hy staan 'n grammaties-historiese hermeneutiek vir eksegese voor, en stel dit dat mense geleer moet word dat God mense wil herstel en nie vernietig nie: "Ware heiligmaking is liefde in aksie."

Die eerste verbandhoudende aspek, naamlik wetenskaplik gefundeerde Woordverkondiging, waarin leraars hermeneuties met die Skrif werk, staan teenoor 'n leer wat hermeneuties gesproke nie getrou is aan die Skrif nie. Net soos die verkeerde gebruik van die Bybel tot dwaling lei, so kan die regte hantering en gebruik mense na Christus terugbring. Dit was met Robert die geval: vanweë opleiding in grammaties-historiese hermeneutiek het hy reeds tydens sy kweekskoolopleiding begin om weg te beweeg van die piëtisme wat hy as lidmaat in sy kerk en later as student by die kweekskool beleef het. Tydens sy studie het hy by 'n Shepherd's Conference met gereformeerde teologie kennis gemaak. Hy het die waarde van 
die eksegesemetodiek waarin hy opgelei is besef, dit begin gebruik, en ontdek dat hy dogmaties gesproke, in sy kerk op 'n pentekostalistiese (Pinkster) of charismatiese belydenispad geneem is. Dit "was vir my 'n skok gewees om te sien in watter lyn ek eintlik basies grootgeword het ... in opgelei is ... dit het my geskok toe ek dit agterkom, want dit was amper vir my misleiding".

'n Tweede verbandhoudende aspek, naamlik akademiese blootstelling sluit aan by die voorafgaande. Dit het Edgar gehelp toe hy in sy nagraadse studie met hermeneuties verantwoorde hantering van die Bybel te doen gekry het. Die akademies verdraagsame atmosfeer waarin hy kon studeer, teenoor die onverdraagsaamheid wat hy tydens sy kweekskoolopleiding ervaar het, het hom oor sy aanvanklike opleiding ontnugter. Hy sê daarvan: "Omdat jy so onskuldig is en so die Here gevind het, jy weet, enigiets sal jy glo ... sonder om eers te vra waar kom dit vandaan". Tydens die nagraadse studie het Edgar ook baie stryd beleef, want "aan die een kant wil jy vashou aan wat jy geleer het, en aan die ander kant word jy gewys dat dit nie so eenvoudig is nie ... dit was vir my baie moeilik". Hy het vanuit 'n hermeneuties verantwoorde begrip van die Bybel besef hy is in piëtisme vasgevang, en dit het hom na 'n oplossing laat soek. Hy bestempel piëtisme as 'n siekte en sê hy is daarvan "genees", want "die manier waarop hierdie ouens dink en dit wat hulle doen, is gevaarlik ... dit kan veroorsaak dat mense patologies raak, godsdienstig siek".

\section{- Tema 2: Ondersteuning van medegelowiges}

'n Tweede tema van ondersteuning van medegelowiges spreek uit Edgar se belewenis. Hy het van die piëtisme as vorm van godsdiensbeoefening en -belewing vrygeraak met die vriendskap en bystand van twee "sterk belese gelowiges", wat hom ondersteun het in wat hy beskryf as 'n "liefdesbegeleiding". Hulle het hom eerlik en sonder veroordeling gehelp. In verband hiermee noem hy ' $n$ baie belangrike faset wat in ag geneem moet word, naamlik dat indien jy die kruk van piëtisme by iemand wegneem, dan moet dit vervang word met iets substansieel wat so 'n persoon kan ondersteun en vorentoe help.

\section{- Tema 3: Gebed}

Gebed is 'n derde tema by die "vrywording" van die piëtisme as vorm van godsdiensbeoefening. Soos vroeër aangedui, is Robert pessimisties oor die moontlikheid dat 'n mens piëtistiese gelowiges tot ander insigte kan beweeg. Hy glo "'n ou kan vir hulle bid, maar 
oortuig gaan jy hulle nie oortuig as die Heilige Gees dit nie doen nie". Amanda glo dat mense wat in dwalings soos piëtisme verstrengel is, met liefde en baie gebed ondersteun moet word om vry te raak.

\section{- Tema 4: Vryheid}

Die tema vryheid word verskillend deur voorheen p-persone verwoord. Marko beskryf dit as "'n vrymaking" van vrees, "die vrees om gedurig te moet perform - die vrees vir die gevolge - is uitputtend". Binne die vryheid sien hy homself "in ' $n$ Vader-kindverhouding van ... myself wees ... juis omdat ek nie meer onder veroordeling staan nie en geen vrees hoef te hê vir 'n God wat my wil bykom oor mislukkings nie". Robert sê: "Die waarheid maak jou meer vry wanneer jy daarby uitkom ... as jy gewoond was aan die leuen". Hy het hom voorgeneem om nie weer in sy lewe "'n slaaf van mense te wees nie, want om 'n slaaf van 'n mens te wees ... maak van jou 'n halwe mens, jy kan nooit die vreugde en die vrede van die Here ervaar nie".

Oor sy vryheid skryf Edgar dat hy, ofskoon hy soms 'n "gevoel van godsdienstige verwarring" beleef, beleef hy nou die "vryheid dat jy vir jouself kan dink". Hy het ook woede beleef. "Jy's kwaad vir hierdie mense omdat hulle so 'n houvas op jou lewe gehad het ... 'n ou wil sommer hulle geloof verwoes". Hiervan sê hy egter: "Jy moenie dit doen nie, ... hierdie ouens is nog steeds lief vir die Here en hulle is ook kinders van die Here en ek dink 'n mens moet hulle net daarop wys op 'n mooi, liefdevolle wyse".

\section{- Tema 5: Om in ooreenstemming met Christus se voorbeeld te lewe}

Die eis om in ooreenstemming met Christus se voorbeeld te lewe, staan teenoor 'n piëtisme van werke, van "jy moet "perform'" (Stephen). Marko sê indien mense verstaan wat God se doel met hulle is, dat hulle nie hoef te "perform" om Hom tevrede te hou nie, dan kom lewensheiliging tot sy reg. Ten einde dit te help bevorder, sê hy: "Ek vat die persoon na Christus dat hy ontdek wat het hy geword en ontvang in Christus. En daarvandaan vat ek hom in eenvoud 'stappender-wys', nie 'stapsgewys' nie, om te ontdek en daarin te groei en weg te kom van al hierdie dinge wat van my nie 'n kind maak nie, maar 'n slaaf."

Amanda, 'n nooit p-persoon nie, beskou dit as noodsaaklik dat gelowiges volgens Christus se voorbeeld sal lewe. Ten einde as 'n 
voorbeeld vir ander te leef, stel sy dit as 'n vereiste om uit te vind "op watter manier het Jesus gedoen" en om ook as 't ware "die Bybel te lees uit Jesus se oë". Dit blyk uit haar stelling dat die bybelse standaard vir 'n toegewyde lewe voorgehou moet word, in plaas van die piëtisme se "gepak" van uiterlike, oppervlakkige "standaarde" wat mense wegjaag. Stephen stem saam met Amanda dat iemand se lewe moet ooreenstem met dit wat Hy verkondig - "ek dink dis hoekom die Here so 'n sterk impak gehad het ... omdat Hy nooit iets gesê het wat teenstrydig was met sy lewe, hoe Hy opgetree het nie".

Stephen is nooit ingetrek in die piëtistiese vorm van godsdiensbeoefening en -belewing nie, en hy meen dat ' $n$ verkondigingswyse waarin die "Woord op 'n ander manier oopgaan" tot die vryheid van mense wat in piëtisme vasgevang is, kan meewerk. Vanweë die geïsoleerdheid waarin sommige piëtisties-gesinde mense lewe, dra hulle nie kennis van "die realiteit, die lewe en wat om hulle alles plaasvind" nie en hulle wil nie by "die hardheid en die wreedheid van die wêreld daar buite" betrokke raak nie. Daarteenoor kan blootstelling aan die realiteit van die lewe "as 'n ou begin betrokke raak en sien die nood en dat ander mense behoeftes vervul" en "blootstelling aan die behoeftes van die gemeenskap ... mense se oë oopmaak".

\subsubsection{Samevatting}

'n Belangrike faktor wat 'n rol kan speel om persone vry te maak van die rigiditeit van die piëtisme, is verantwoorde Skrifhantering. Dit is duidelik dat sommige persone vrygeraak het van die knelling van die piëtisme toe hulle hermeneuties verantwoord met die Skrif begin werk het. Hiertoe het verdere akademiese blootstelling positief bygedra. Die noodsaaklikheid dat leraars hermeneuties verantwoord met die Skrif moet werk, word beklemtoon. Dit blyk verder dat liefdevolle ondersteuning van medegelowiges, ook deur gebed, noodsaaklik is om gelowiges te help om vry te raak van piëtisme. Medegelowiges se uitlewing van hulle geloof - in ooreenstemming met Christus se voorbeeld - kan ook 'n rol speel om persone van piëtisme te "bevry".

Piëtisme kan dus voorkom word deur 'n grammaties-historiese hermeneutiek, waarin die gereformeerde teologie sy regmatige plek beklee en die Skrif onbevange bestudeer kan word. Tweedens kan die liefdevolle naleef van Christus deur medegelowiges wat nie piëtisties gesind is nie, iemand help om vry te kom. Gebed vir gelowiges wat in piëtisme vasgevang is, is noodsaaklik. 


\section{Praktykteoretiese perspektiewe}

Die data wat basisteoreties en empiries ontgin is, kon sinvol geanaliseer en geïnterpreteer word om die navorsingsvraag te beantwoord. Die narratiewe navorsingsmetode en die prosesmatige ontleding van die data is volgens die outeurs 'n vars benadering tot hierdie navorsingsarea en nuwe insigte kon sodoende bekom word.

Die belangrikste gevolgtrekkings wat in die ondersoek na vore gekom het, is die volgende:

- Mense raak betrokke by hierdie vorm van piëtisme vanweë die leer wat 'n tweede genadewerk vereis om die probleem van inwonende sonde op te los.

- 'n Gesonde, bybelse leer kan voorkom dat mense die leer van die piëtisme aanhang.

- Die negatiewe en soms ongeloofwaardige wyse waarop die vereistes van die piëtisme uitgeleef word, weerhou mense soms daarvan om piëtisme as wyse van godsdiensbeoefening te aanvaar.

- Die geloofsekerheid dat iemand die genadewerk ontvang het, 'n geslote godsdienssisteem, en godsdienstige euforie kan veroorsaak dat mense vasgevang bly in die godsdienspatrone van die piëtisme.

- Die raaksien dat die piëtistiese leer nie hermeneuties getrou is nie, die ondersteuning deur medegelowiges en hulle gebede, en medegelowiges se voorbeeldige lewe ooreenkomstig Christus se voorbeeld, kan mense egter uit hierdie vorm van piëtisme bevry.

'n Verrassende en onrusbarende aspek wat uit die narratiewe van die deelnemers na vore gekom het, is die liefdelose uitlewing van hierdie vorm van piëtisme deur sommige aanhangers daarvan. Die ervaring van die negatiewe aspekte van hierdie vorm van piëtisme, kan egter juis daartoe meewerk om iemand daarvan te bevry of hom/haar verhoed om by hierdie piëtistiese godsdiensbelewing betrokke te raak.

Hierdie navorsingsresultate bied belangrike inligting wat deur kerke, beraders en medegelowiges toegepas kan word om hierdie vorm van piëtisme teen te staan, of om mense wat daaruit bevry wil word, te begelei. Belangrike aspekte in hierdie verband is die volgende: 
- Suiwer en gefundeerde Woordverkondiging is stellig die belangrikste faktor om piëtisme teen te werk en bevryding daaruit te bied. Gesonde teologiese blootstelling van lidmate is hiervoor noodsaaklik. Teologiese opleiding wat op 'n breë bybelkundige basis geskoei is en op hermeneuties verantwoorde eksegese ingestel is, kan leraars se eensydige indoktrinasie om binne 'n geslote sisteem met slegs dié kerk se leer en tradisie te werk, ondervang.

- Dit is noodsaaklik dat gelowiges mekaar in die gemeente, binne die gemeenskap van die liggaam van Christus, teen die piëtistiese leer en die uitvloeisels daarvan moet beskerm. Die negatiewe aspekte van piëtisme waarna verwys is, kan teengewerk word deur die betoning van Christelike liefde teenoor mekaar, asook gebede vir mekaar.

- By mense wat in 'n piëtistiese godsdiensgemaksone verkeer, moet 'n bewustheid gekweek word oor die nood van andere, en hulle moet aangemoedig word om betrokke te raak by barmhartigheid en die betoning van naasteliefde. Fasiliterende strukture binne die gemeente om so 'n betrokkenheid in die samelewing te bevorder en in stand te hou, is hiervoor noodsaaklik.

- Beraders moet iemand wat die leer van die piëtisme aanhang in die bybelse leer oor lewensheiligheid begelei deur middel van 'n duidelike uiteensetting van die omvattendheid van verlossing en die daarmee gepaardgaande toewyding aan Christus. As iemand weet wat die bybelse begrip van sonde behels, kan hy ook insien hoe hy volgens die Bybel moet lewe. Dit mag wees dat die vormgodsdiens van die piëtisme God se plek by 'n gelowige kan inneem (Nicholls, 1996:10). In die beradingsproses sal werkers op hierdie moontlikheid bedag moet wees. Beraders moet mense wat berading ontvang terugbring na die werklikheid van die lewe waarin God ons hoogste goed is, en hulle begelei tot 'n lewe waardeur Hy geëer word.

Vanweë die relatief klein aantal deelnemers wat by hierdie navorsing betrek is, asook die feit dat die meeste deelnemers predikante was, sou dit sinvol wees om in toekomstige navorsing oor hierdie vorm van piëtistiese godsdiensbeoefening meer deelnemers wat nie predikante is nie, te betrek. Sodoende sou aangedui kan word in hoe 'n mate lidmate se belewenisse van hierdie vorm van piëtistiese godsdiensbeoefening ooreenstem met die gegewens wat verkry is uit hierdie navorsing, al dan nie. Hierdie navorsingsresultate kan ook gebruik word om 'n vraelys op te stel wat aan lidmate versprei kan 
word indien 'n navorser sou verkies om 'n kwantitatiewe studie in gemeentes te onderneem, in plaas van 'n kwalitatiewe studie.

\section{Geraadpleegde bronne}

ANDERSON, H. \& GOOLISHIAN, H.A. 1988. Human systems as linguistic systems: preliminary and evolving ideas about the implications for clinical theory. Family process, 27(4):371-393.

ANON. 2006. Pietism. http://en.wikipedia.org/wiki/Pietism Date of access: 7 Oct. 2006.

BERG, B.L. 2007. Qualitative research methods for the social sciences. Massachusetts: Allyn \& Bacon.

BEUKES, R.D. s.a. 1 Kor. 3:1-8. Die vleeslike lewe: die lewe in die woestyn. [Kassetopname.]

BLOEMHOF, F. 1970. Eenvoudig leerboek der kerkgeschiedenis. Nijkerk: Callenbach.

BOTES, A. 2003. Validity, reliability \& trustworthiness: to sum up. (In Rossouw, D., ed. Intellectual tools: skills for the Human Sciences. Trans. by C. Fourie. Pretoria: Van Schaik. p. 176-184.)

BRAUN, V. \& CLARKE, V. 2006. Using thematic analysis in psychology. Qualitative research in Psychology, 3:77-101.

BRENNER, J.M. 2007. Pietism: past and present. http://www.wlsessays.net/ authors/B/BrennerPietism/BrennerPietism.pdf Date of access: 22 Mar. 2007.

BYBEL. 1983. Nuwe Afrikaanse Vertaling (NAV). Kaapstad: Bybelgenootskap van Suid-Afrika.

BYBEL. 1988. Nestlé-Aland: Novum Testamentum Graece. Stuttgart: Deutsche Bibelgesellschaft.

BYBEL. 1999. Ou Afrikaanse Vertaling (OAV). Goodwood: Bybelgenootskap van Suid-Afrika.

CHUNG, S.W. 1995. Recovering God's sovereign grace: the Arminian captivity of the modern Evangelical Church. Alliance of confessing evangelicals: life under the big top, 1-7, Jan./Feb.

CILLIERS, J. 1997. Die uitwissing van God op die kansel: ontstellende bevindinge oor Suid-Afrikaanse prediking. Kaapstad: Lux Verbi.

CLOUD, D.W. 2007. False views of sanctification refuted. http//www.wayoflife. org Date of access: 1 Mar. 2007.

COETZEE, F.S. s.a. Dogmatiek lesing I-XIII. Heidelberg: Seminarie van die Evangelies-Gereformeerde Kerk van Suid-Afrika.

COETZEE, F.S. 2007. Word heilig gemaak. Evangelies-Gereformeerde Kerkblad, 62(557):6, Mei-Jun.

DE VOS, A.S., STRYDOM, H., FOUCHE, C.B., \& DELPORT, C.S.L. 2002. Research at grass roots: for the social sciences and human service professions. Pretoria: Van Schaik.

HOEKEMA, A.A. 1996. The reformed perspective. (In Dieter, M.E., Hoekema, A.A., Horton, S.M., McQuilkin, J.R. \& Walvoord, J.F., eds. Five views on sanctification. Grand Rapids: Zondervan. p. 61-101.)

JOHNSON, D. \& VANVONDEREN, J. 1991. The subtle power of spiritual abuse: recognizing and escaping spiritual manipulation and false spiritual authority within the church. Minnesota: Bethany House. 
KÖNIG, A. 2006. Die groot geloofswoordeboek. Vereeniging: Christelike Uitgewers Maatskappy.

LIEBLICH, A., TUVAL-MASHIACH, T. \& ZILBER, T. 1998. Narrative research: reading, analysis and interpretation. London: Sage.

LOUW, J.P. \& NIDA, E.A. 1988. Greek-English lexicon of the New Testament based on semantic domains. Vol. 1, 2. New York: United Bible Societies.

MACARTHUR, J.F. 1992. Charismatic chaos. Grand Rapids: Zondervan.

MACARTHUR, J.F. 1994. The gospel according to Jesus. Grand Rapids: Zondervan.

MACARTHUR, J.F. 2000. The gospel according to the apostles: the role of works in the life of faith. USA: Nelson Books.

MIENIE, J.D. 2009. Jesus, ons Heiligmaker. Evangelies-Gereformeerde kerkblad, 64(568):4, Mrt.-Apr.

NEUMAN, W.L. 2000. Social research methods: qualitative and quantitative approaches. Boston: Allyn \& Bacon.

NICHOLLS, W. 1996. Saints and fanatics: the problematic connection between religion and spirituality. Judaism, 45(4):446-460. http//www.puk.ac.za Date of access: 3 Sept. 2005.

PEARSON, R.S. 2005. Identifying and overcoming patterns of religious dysfunction. www. Hyperreligiosity as a psychological term for religious addiction and toxic faith.htm Date of access: 14 Oct. 2006.

POGGENPOEL, M. 2003. The research interview. (In Rossouw, D., ed. Intellectual tools: skills for the Human Sciences. Trans. by C. Fourie. Van Schaik: Pretoria. p. 143-150.)

ROUSSEAU, P.A. 2010. Noutetiese berading van persone met piëtistiese mistastings oor lewensheiligheid. Potchefstroom: Noordwes-Universiteit. (Ph.D.-proefskrif.)

SAAYMAN, C. 2006. Historiese rede waarom die NG Kerk is waar hy tans is. Lesing 2: Voëlvlug oor die kerkgeskiedenis. http://www.nmgtading.co.za Datum van gebruik: 14 Apr. 2007.

SONG, M.H. 1998. Pauline pneumatology: new life through the Spirit in the four major letters of Paul. Potchefstroom: North-West University. (D.Th. thesis.)

TORREY, R.A. 1967. The Holy Spirit who He is and what He does. Trans. by T. Kriel. Kemptonpark: Hart-kolportasie-boekery.

TRAKAKIS, N. 2005. Theandros. Journal of orthodox Christian theology and philosophy, 2(3), Spring. http://www.theandros.com/pietism.html Date of access: 2 Sept. 2006.

YANNARAS, C. 1984. Pietism as a heresy: from the freedom of morality. Crestwood: St. Vladimir's Inary Press.

\section{Kernbegrippe:}

lewensheiligheid

narratiewe analise

piëtisme: ervaring van

piëtistiese godsdiensbeoefening

tweede genadewerk, leer van die 


\section{Key concepts:}

holiness of life

narrative analysis

pietism: experience of

pietistic religious practice

second blessing, doctrine of the 
$\underline{\text { Piëtisme en die wyse waarop die sogenaamde "second blessing"... Praktiese Teologie }}$ 